\title{
VOLATILITY OF JAKARTA ISLAMIC INDEX
}

\author{
Hendri Tanjung ${ }^{1}$
}

\begin{abstract}
Volatility of Jakarta Islamic Index. This study investigates the volatility of Jakarta Islamic Index (JII) in Jakarta Stock Exchange. The method that used in this research is used a simple statistical analysis. The normality of JII return is analyzed to answer whether the return of JII follows normal distribution. By using data of Jakarta Islamic Index from $2^{\text {nd }}$ March 2009 to $30^{\text {th }}$ October 2013 (1122 daily data), it is found that the distribution of return of JII is not normal, even the 5 sigma occurred. This means the return of Jakarta Islamic Index is much volatile than the theory predicted. This will make too much gain or loss in one day in the economy.
\end{abstract}

Keywords: Volatility, normal distribution, Jakarta Islamic Index

Abstrak: Volatilitas Jakarta Islamic Indeks. Penelitian ini melakukan investigasi terhadap volatilitas Jakarta Islamic Index (JII) pada Jakarta Stock Exchange. Teknik analisis yang dipergunakan dalam penelitian ini hanya analisis statistic sederhana. Kenormalan distribusi dari tingkat return pada JII dianalisis untuk menjawab apakah return nya menyebar normal atau tidak. Dengan menggunakan data Jakarta Islamic Index dari 2 Maret 2009 sampai 30 Oktober 2013 (1122 data harian), ditemukan bahwa distribusi dari return JII tidak menyebar normal, bahkan 5 sigma terjadi. Penelitian ini menyimpulkan bahwa return dari Jakarta Islamic Index sangat berfluktuasi, melebihi apa yang teori jelaskan. Implikasinya adalah, akan diperoleh keutungan yang sangat tinggi dan kerugian yang sangat besar pada suatu hari, dalam ekonomi.

Kata Kunci: Volatilitas, Distribusi Normal, Jakarta Islamic Indeks

${ }^{1}$ Diterima: 15 Maret 2014, direvisi: 15 April 2014, disetujui: 28 April 2014

Universitas Ibn Khaldun, Jl. Sholeh Iskandar, Km. 2, Bogor. Email: hendri.tanjung@gmail.com 


\section{INTRODUCTION}

There is a book title "When Genius Failed" by Roger Lowenstein (2001) that tells the story of two prominent economists. One of them is the Nobel Prize winner for his contributions in the field of financial econometrics. They both ran hedge funds company which is named 'Long Term Capital Management' (LTCM). All people were vying to invest money through the LTCM because of the one of founding fathers was a Nobel Prize winner. They believed that the company would not collapse. How could LTCM collapsed while his partner is a champion in that field? That was the belief in the mind of the investors at the time.

LTCM used highly sophisticated calculations by assuming that the return has a normal distribution. With this calculation, investors could calculate the probability to get certain benefits. For four years, LTCM showed very good performance with high margins. All investors were stunned. However, one day, after four years dazzling Wall Street as a huge moneymaker 100 billion U.S. dollars, everything was over.

Because LTCM managed huge money, so when they collapsed, the stock market collapsed as well. To avoid the breakdown of all aspects of the economy due to loss of capital markets, the U.S. Federal Reserve had stepped in to help by pumping money into LTCM.

As a response to this event, Lowenstein writes:

On account of a crisis at LTCM, Mc Donnough had summoned - "invited", in the Fed restrained idiom-The head of every major Wall Street Bank. For the first time, The chiefs of Bankers trust, Bear Stearns, Chase Manhattan, Goldman Sachs, J.P. Morgan, Lehman Brothers, Merrill Lynch, Morgan Stanley Dean Witter, and Salomon Smith Barney, gathered under the oil portraits in the Fed's tenth floor boardroom —not to bail out a Latin American Nation but to consider a rescue of one of their own.

The question that arises is of course, why did these two geniuses fail? Is it true as they assumed that the return of stock market follows the normal distribution? The problem statements are: (1) Is the distribution of return on the JII normal or not?; (2) What is the volatility of the returns of JII?

The purpose of this study are: (1) To analyze whether the distribution of return on the JII normal or not. (2) To show the volatility of the returns of Jakarta Islamic Index (JII). At the end of this study, there will be recommendation regarding the findings.

\section{LITERATURE REVIEW}

There was at least fifteen historical episodes of stock market crashes in the 
United States over the last one hundred years, and Mishkin and White (2002) argue that financial instability is the key problem facing monetary policy makers. Some authors showed that instability of capital market is a common phenomenon found everywhere. Igbatayo (2011) found that instability in financial market (banks and capital market) occured in Nigeria. In the capital market, equity prices in the past couple of years, have fallen sharply, with the All-share index at the Nigerian Stock Exchange down by 33 percent at the end of December 2009, from levels recorded in December, 2008. Butt (2010) found the instability of return of stock market in Pakistan. He argued there is relationship between risk and return in Karachi Stock Exchange 100 index.

Edwards, Biscarri and de Gracia (2003) analyzed the cycles of the stock markets in four Latin American (Argentina, Brazil, Chile and Mexico) and two Asian countries (South Korea and Thailand), and compared their characteristics. They found that cycles in emerging countries tend to have shorter duration, larger amplitude and volatility than in developed countries. Some authors related the stock market with the political development and economic growth. Asteriou and Siriopoulos (2003) examined empirically the relationship between stock market development, political instability and economic growth in Greece. Using time series data, the results indicated that there was a strong negative relationship between uncertain socio-political conditions and the general index of Athens Stock Exchange (ASE) and supported the theoretical hypothesis that uncertain socio-political conditions affect economic growth negatively, is true for Greek case. Konzelmann et.al.(2010) argued that at the heart of the crisis was a breakdown in governance that has it roots in the co-evolution of political and economic developments and of economic theory and policy since 1929 stock market crash and the Great Depression that followed.

Some authors argued that the cause of volatility in stock market is not political uncertainty, but other factors. Voth (2001) found that the majority of events increasing political uncertainty had little or no effect on the value of German assets and the volatility of returns on them. Instead, it was inflation (and the fear of it) that is largely responsible for most of the variability in asset returns. Panetta (2002) argued that the relation between stock returns and the macroeconomic factors was found to be unstable in Italia. Miller and Ratti (2009) found negative relationship between the world price of crude oil and international stock markets in the last decade. This may suggested the presence of several stock market bubbles.

Yusof and Madjid (2007) found that interest rate volatility affected the conventional stock market volatility but not the Islamic stock market volatility in Malaysia. This highlights the tenet of Islamic principles that the interest rate is not a significant variable in explaining stock market volatility. Their finding provides 
further support that stabilizing interest rate would have insignificant impact on the volatility of the Islamic stock markets.

There are at least eight models to explain the volatility in stock market. They are overreaction model, adverse impact of related laws, increasing linkages model, transmission of volatility model, adverse impact of derivatives' model, adverse impact of related markets' model, impact of volume volatility model, and econophysics' model of stock market crises. Shabri (2002) explored the causes of stock market prices and high price volatility in several countries. He found that very high volatility which indicated by more than $50 \%$ change occured in several countries, i.e. Amsterdam, Athens, Belgia, Italia, Spain, Swiss, Mexiko, Argentina, Korea, malaysia, Thailand and Turkey.

We may summarize that volatility of stock market occured everywhere in the world. Some researchers tried to explain the roots, the causes and the relations of stock market volatility with some other factors. In this study, we focus on analyzing the magnitude of the volatility of Jakarta Islamic Index and the consequence of that into economy.

\section{METHODS}

The data are collected from Jakarta Stock Exchange (JSX), Indonesia. The data are the return of Jakarta Islamic Index (JII) from $2^{\text {nd }}$ march 2009 to $30^{\text {th }}$ september 2013. This study analyzes 1122 daily data of return of JII.

This study does not use sophisticated model to explain the volatility of return of stock market such as overreaction model, adverse impact of related laws, increasing linkages model, transmission of volatility model, adverse impact of derivatives' model, adverse impact of related markets' model, impact of volume volatility model, and econophysics' model of stock market crises. Instead, this study uses simple statistical analysis, i.e., Time series Plot to see the fluctuation of data, Histogram to see the pattern of distribution, and QQ plot to analyze the normality of return of Jakarta Islamic Index (JII) data. QQ plot is a probability plot, which is a graphical method for comparing two probability distributions by plotting their quantiles againts each other.

\section{DISCUSSION}

It is important to see the daily data of Jakarta Islamic Index (JII) in Jakarta Stock Exchange (JSX) and try to find out if the return is normal or not. People think that it is normal, even though really it is not. 
First of all, the time series plot of the return for all data will be seen. The data consist of 1122 observations, from $2^{\text {nd }}$ March 2009 to $30^{\text {th }}$ September 2013. The time series plot can be seen in Figure 1 .

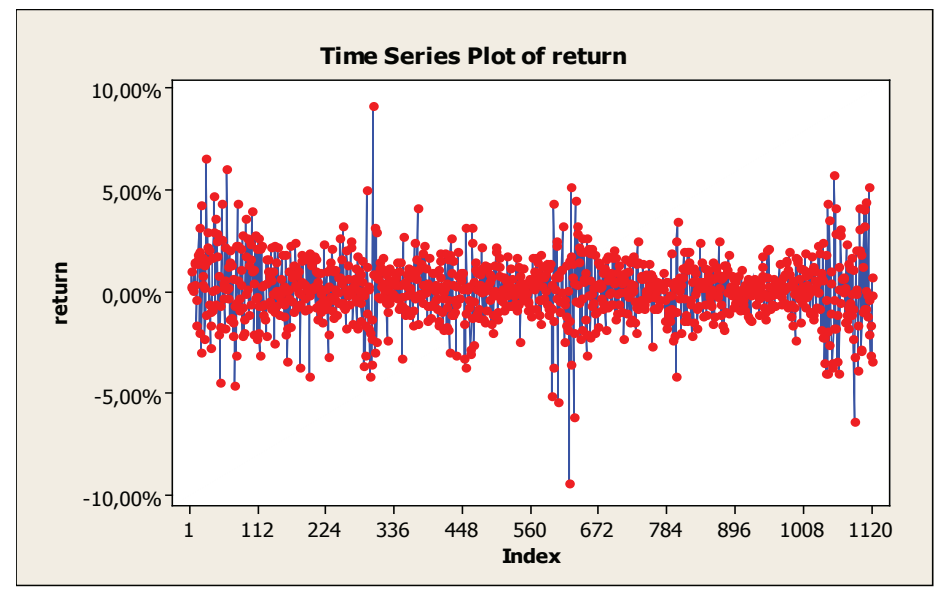

Figure 1. Time Series Plot of JII return from $2^{\text {nd }}$ March 2009 to $30^{\text {th }}$ September 2013 (1122 data)

From figure 1, it could be seen that minimum return is almost $-10 \%$ and maximum is almost $10 \%$. This shows that in one day, there is probability to gain almost 10 percent and to loss almost 10 percent. If we see the data comprehensively, we could split the data into four parts based on its volatility. The first part is from $1^{\text {st }}$ observation to $300^{\text {th }}$ observation ( $300 \mathrm{data}$ ). The second part is from $301^{\text {th }}$ to $600^{\text {th }}$ observation (300 data). The third part is from $601^{\text {th }}$ to $900^{\text {th }}$ observation (300 data) and the last part is from $901^{\text {th }}$ to $1122^{\text {th }}$ observation (222 data). In the next subchapter, we will discuss the first part, the first 2 parts, the first 3 parts, and all parts separately. But before analysis of the four parts be done, it is important to check for 100 observations which is approximately 4 months observations.

\section{0 observations}

Consider 100 observations of Jakarta Islamic Index (JII). Those are data from $2^{\text {nd }}$ March 2009 to $28^{\text {th }}$ July 2009 (see Appendix). Every day the price of stock fluctuates.

Every minutes the price changes. On $2^{\text {nd }}$ March 2009, the maximum price is 214.042 , the minimum price is 208.330 and at the end of the day, the price of these stock is 209.418 (closing price).

There is $0.26 \%$ gain from $2^{\text {nd }}$ to $3^{\text {rd }}$ March $2009.0 .26 \%$ is obtained by dividing closing price on $3^{\text {rd }}$ March which is 209.959 with closing price on $2^{\text {nd }}$ 
March 2009 which is 209.418 . The result is $100.26 \%$. This means $0.26 \%$ increase within one day and it is gain. If we had stocks on $2^{\text {nd }}$ March and we sell it on $3^{\text {rd }}$ March (one day later), we will gain $0.26 \%$. On the other hand, there is $1.67 \%$ loss from $16^{\text {th }}$ to $17^{\text {th }}$ March 2009 . $1.67 \%$ is obtained by dividing closing price on $17^{\text {th }}$ March which is 215.049 with closing price on $16^{\text {th }}$ March 2009 which is 218.707 . The result is $98.33 \%$. This means $1.67 \%$ decrease within one day and it is loss.

To assess whether those 100 observations follow normal distribution, Q-Q Plot is used. Actually, people usually assess normality by using $68 \%, 95 \%$ and $99,7 \%$ rules. If data follows normal distribution; by using $68 \%$ rule we could say that $68 \%$ of the data between -1 std and +1 std, by using $95 \%$ rule we could say that $95 \%$ of the data between -2 std and +2 std and by using $99,7 \%$ rule we could say that $99,7 \%$ of the data between -3 std and +3 std. Std stands for Standard Deviation. This rule is just checking normality with 3 points, but with Q-Q plot, we assess all points of the data. It is just a slight generalization.

First of all, we look at the histogram of the returns. The result is like Figure 2.

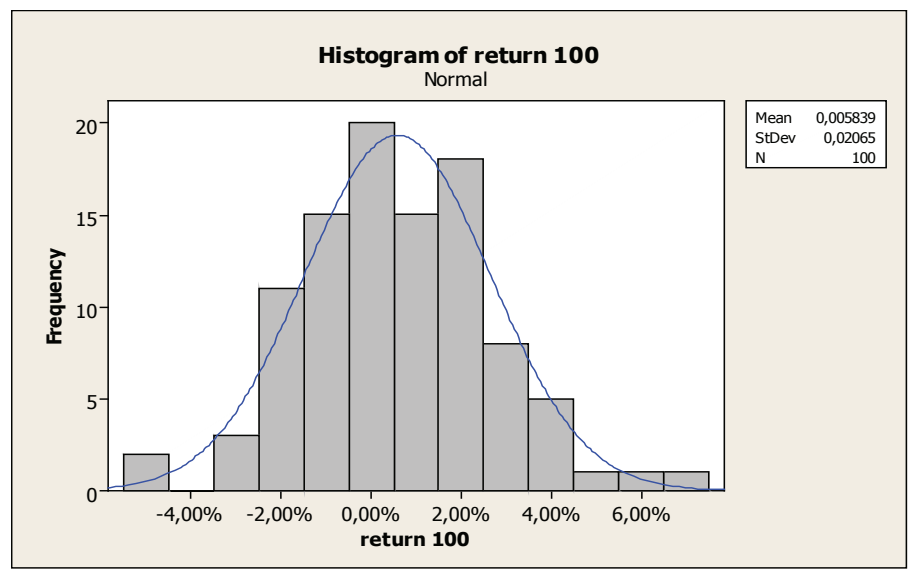

Figure 2. Histogram of return of JII (100 observations) from $2^{\text {nd }}$ march to $28^{\text {th }}$ July 2009

In figure 2, that the distribution is likely normal. Next, Q-Q plot is used to assess the normality of the data. The ' $Q$ ' in Q-Q plot stands for Quintile-Quintile. Quintile is also called percentile. The Q-Q plot of this data is as Figure 3. 


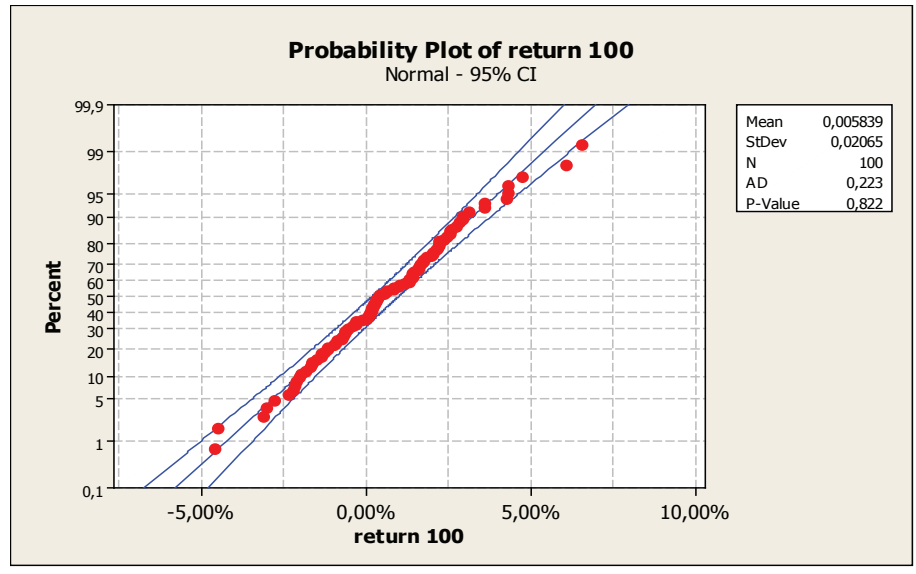

Figure 3. Probability plot of JII Return (100 observations) from $2^{\text {nd }}$ march to $28^{\text {th }}$ July 2009

Figure 3 show that the data seems normal distribution. There are only two observations outside the limit line. The data almost forms 45 degree line. Anderson Darling test is 0.223 with $\mathrm{p}$ value 0.822 . This means that null hypothesis which mentions that the distribution is normal could not be rejected. This shows that the distribution of return of JII for 100 data is normal.

\section{The first year data (300 Observations)}

100 observations are only 4 months data. Now, we want to know the distribution of one year data, which is approximately 300 observations. Time series plot for 300 observations can be seen at Figure 4 .

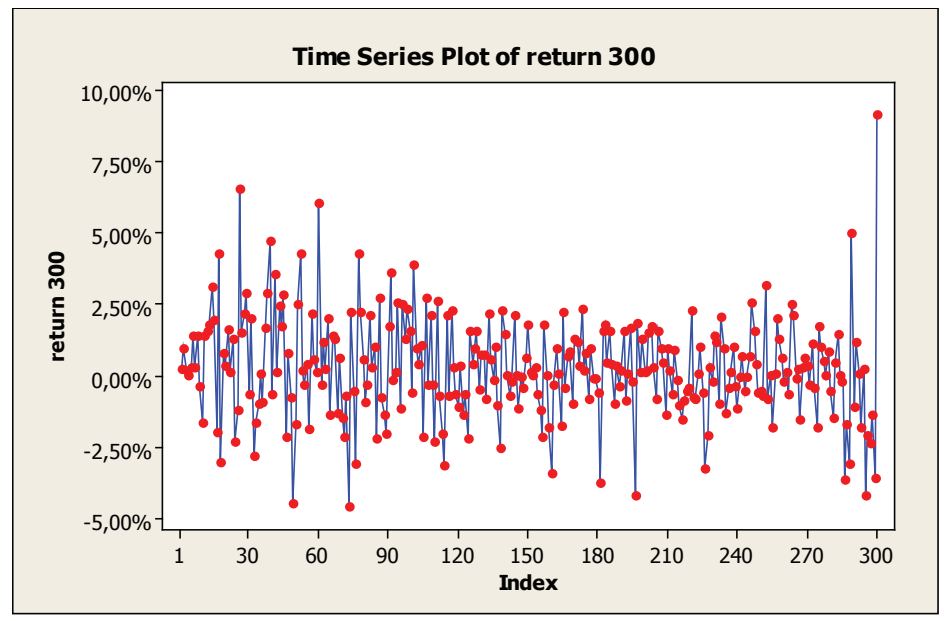

Figure 4. Time Series Plot of JII Return (300 Observations) from 2 March 2009 to 26 May 2010 
Figure 4 explains that most of the volatility of return vary from $-5 \%$ to $5 \%$, although the gain/loss of some observations are bigger than $5 \%$. To see the distribution, histogram is performed. The histogram of 300 observations is captured as Figure 5.

Figure 5 shows that the return of 300 observations is slightly not normal. We can see that 5 sigma occurs. 5 sigma is $8.94 \%$. This is calculated by multiplying 5 with standard deviation $(0,01788)$. The gain more than 8 persen happens in the period of one year from $2^{\text {nd }}$ march 2009 to $26^{\text {th }}$ May 2010. The gain from $25^{\text {th }}$ to $26^{\text {th }}$ may 2010 is $9,15 \%$. This is the evidence that the distribution slightly not normal. If the data is normal, the probability of 5 sigma is 3 out of $10,000,000$. But in this data, the probability is 1 out of 300 . To investigate the normality of distribution, Anderson Darling test and QQ Plot are used. Figure 6 shows the result.

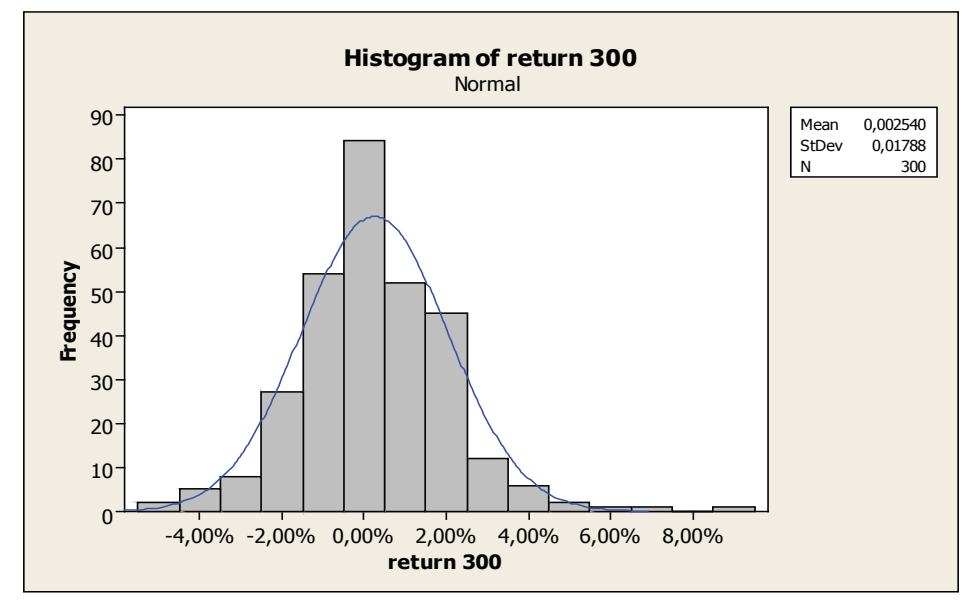

Figure 5. Histogram of return of JII (300 observations)

from 2 march 2009 to 26 May 2010

From the figure 6, it could be concluded that the distribution of 300 observations is not normal. Anderson darling test is 1,369 with P-Value $<0.005$. This means that the null hypothesis is rejected. The null hypothesis is the distribution is normal. When the null hypothesis is rejected, it means that the distribution is not normal.

Now, The result show normality in small sample (100 observations) and non normality in larger sample (300 observations). This confirms that the volatility in large sample is bigger than small sample. 


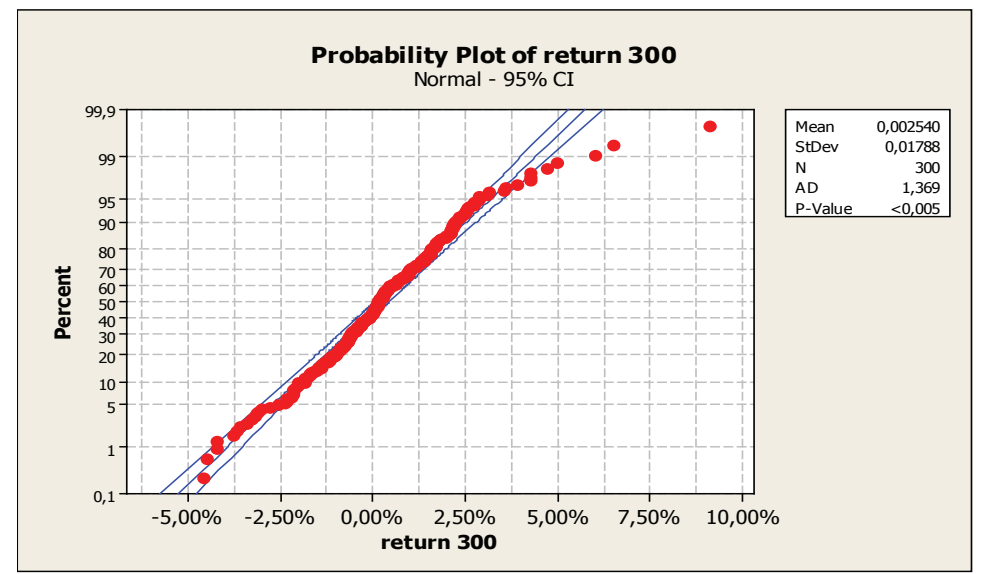

Figure 6. Probability Plot of return of JII (300 observations) from $2^{\text {nd }}$ march 2009 to $26^{\text {th }}$ May 2010

\section{The first 2 years data (600 observations)}

300 observations are only one year data. Now, we want to know the distribution of two years data, which are approximately 600 observations. Time series plot for 600 observations can be seen at Figure 7 .

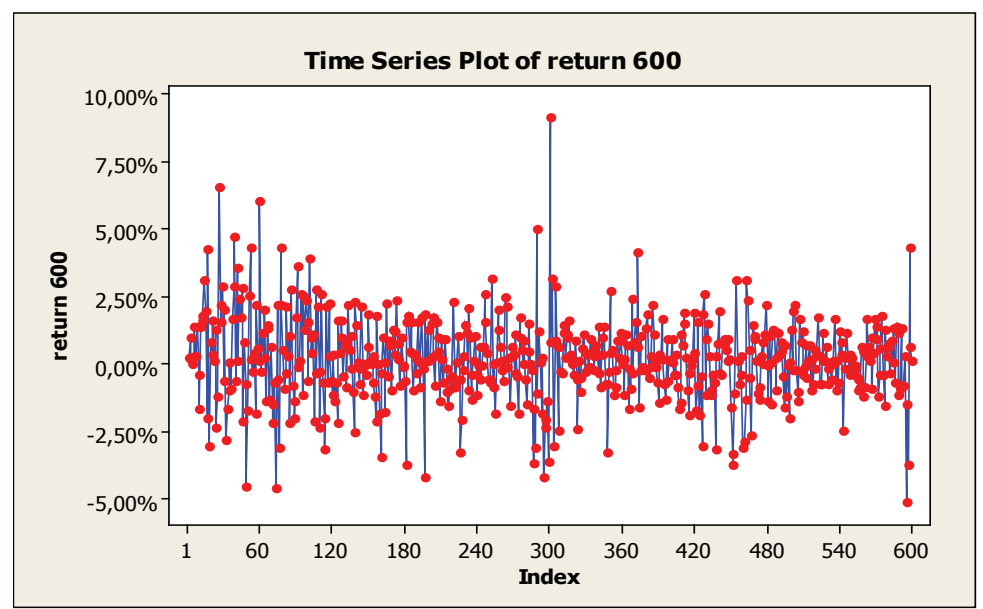

Figure 7. Time Series Plot of JII Return (600 observations) from $2^{\text {nd }}$ march 2009 to $12^{\text {th }}$ august 2011

Figure 7 explains the volatility of return vary from $-5 \%$ to $5 \%$, although the gain/loss of some observations are bigger than $5 \%$. To see the distribution, histogram is performed. The histogram of 600 observations is captured in figure 8 . 


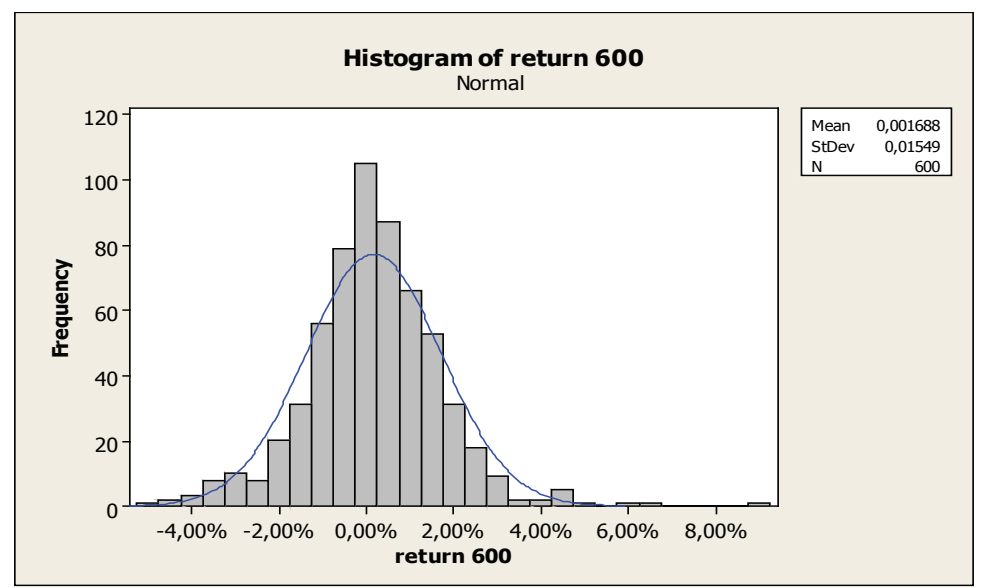

Figure 8. Histogram of JII return (600 observations) from $2^{\text {nd }}$ march 2009 to $12^{\text {th }}$ August 2011

Figure 8 shows that the return of 600 observations is not normal. Even, that 6 sigma occurs. 6 sigma is $9.29 \%$. This is calculated by multiplying 6 with standard deviation $(0,01549)$. The gain more than 9 persen happens in the period of two year from $2^{\text {nd }}$ march 2009 , i.e. at $26^{\text {th }}$ May 2010. This is the evidence that the distribution is not normal. If the data is normal, the probability of 6 sigma is 1 out of $1,000,000,000$. But in this data, the probability is 1 out of 300 . To investigate the normality of distribution, Anderson Darling test and QQ Plot are used. Figure 9 shows the result.

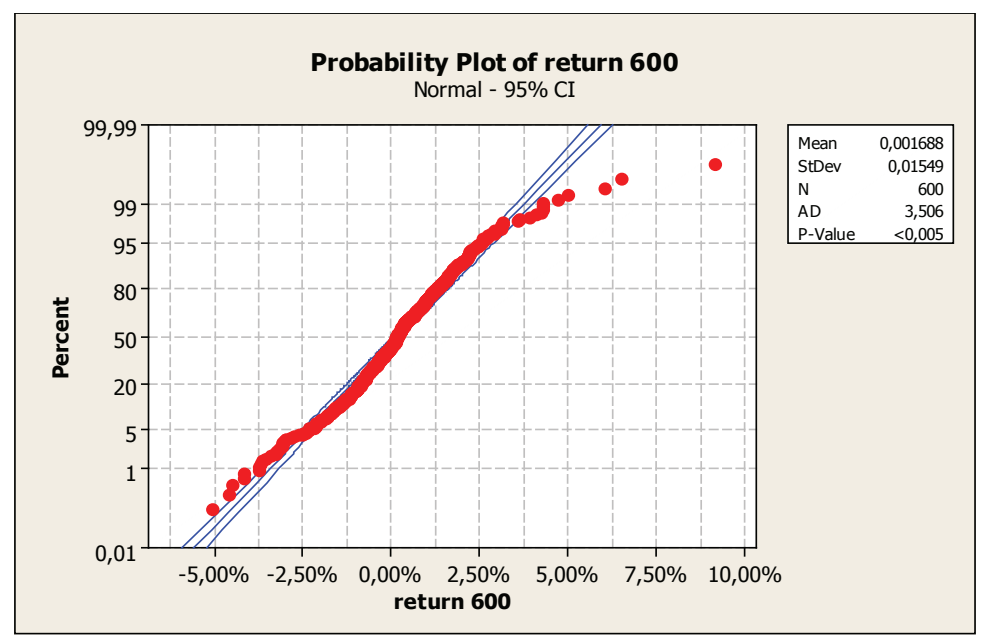

Figure 9. Probability Plot of JII return (600 observations) from 2 ${ }^{\text {nd }}$ March 2009 to $12^{\text {th }}$ August 2011 
From figure 9 it could be concluded that the distribution of 600 observations is not normal. Anderson Darling test is 3,506 with P-Value $<0.005$. This means that the null hypothesis is rejected. The null hypothesis is the distribution is normal. When the null hypothesis is rejected, it means that the distribution is not normal.

Now, the result shows normality in small sample (100 observations) and non normality in larger sample (300 observations and 600 observations). This confirms that the volatility in large sample is bigger than small sample.

\section{The first 3 years data}

600 observations are only two year data. Now, we want to know the distribution of three years data, which is approximately 900 observations. Time series plot for 900 observations can be seen at Figure 10.

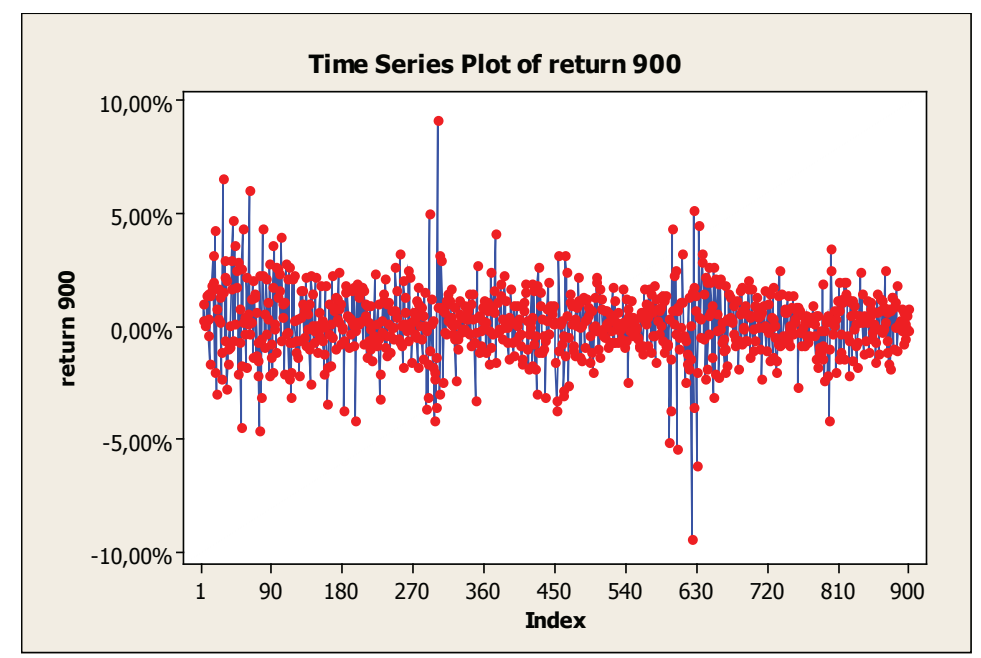

Figure 10. Time Series Plot of JII Return (900 observations) from $2^{\text {nd }}$ March 2009 to $30^{\text {th }}$ October 2012

Figure 10 explains most of the volatility of return vary from $-5 \%$ to $5 \%$, although the gain/loss of some observations are bigger than 5\%. To see the distribution, histogram is performed. The histogram of 900 observations is captured in figure 11. 


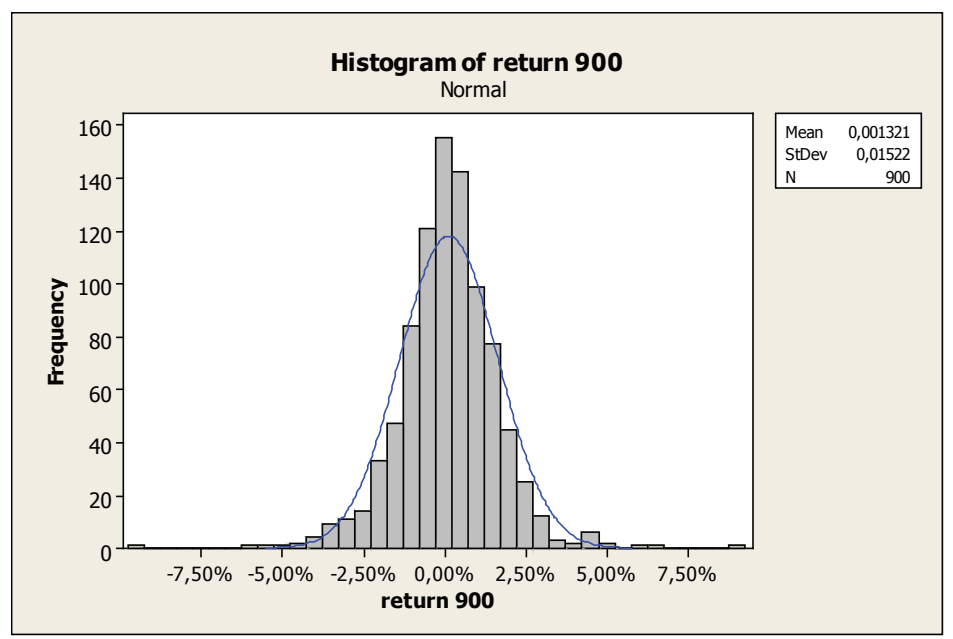

Figure 11. Histogram of JII Return (900 observations) from $2^{\text {nd }}$ March 2009 to $30^{\text {th }}$ October 2012

Figure 11 shows that the return of 900 observations is not normal. Even, that 6 sigma occurs. 6 sigma is 9.13\%. This is calculated by multiplying 6 with standard deviation $(0,01522)$. The gain more than $9.13 \%$ happens in the period of three year from $2^{\text {nd }}$ march 2009 , i.e. at $26^{\text {th }}$ may 2010. This is the evidence that the distribution is not normal. If the data is normal, the probability of 6 sigma is 1 out of $1,000,000,000$. But in this data, the probability is 1 out of 900 . To investigate the normality of distribution, Anderson Darling (AD) test and QQ Plot are used. Figure12 shows the result.

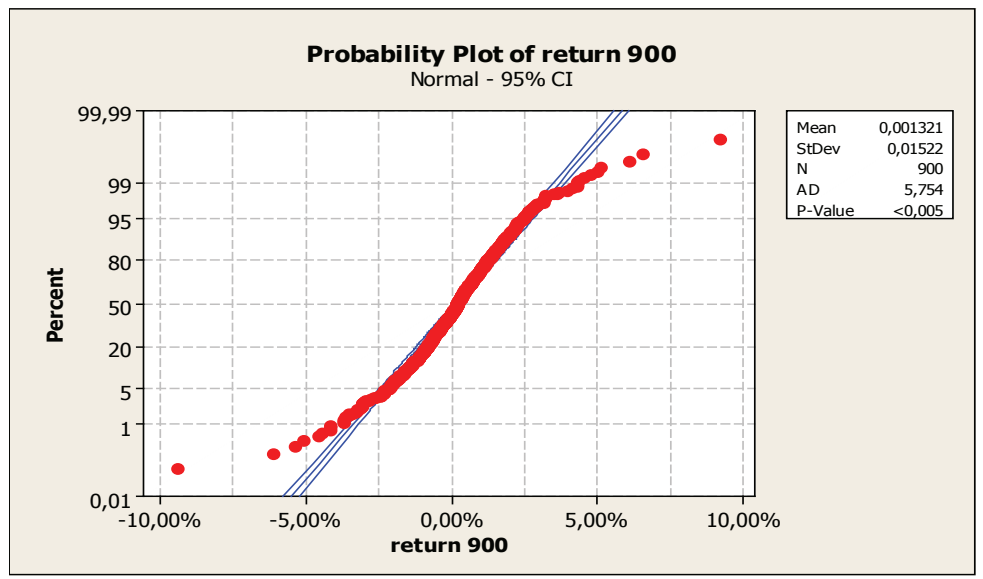

Figure 12. Probability Plot of JII Return (900 observations) from $2^{\text {nd }}$ March 2009 to $30^{\text {th }}$ October 2012 
From figure 12 it could be concluded that the distribution of 900 observations is not normal. Anderson Darling (AD) test is 5,754 with P-Value $<0.005$. This means that the null hypothesis is rejected. The null hypothesis is the distribution is normal. When the null hypothesis is rejected, it means that the distribution is not normal.

Now, the result shows normality in small sample (100 observations) and non normality in larger sample (300 observations, 600 observations and 900 observations). This confirms that the volatility in large sample is bigger than small sample.

\section{All data (1122 Observations)}

900 observations are only three year data. Now, we want to know the distribution of all data, which are 1122 observations. Time series plot for 1122 observations can be seen at Figure 1.

Figure 1 explains the volatility of return vary from $-5 \%$ to $5 \%$, although the gain/loss of some observations are bigger than $5 \%$. To see the distribution, histogram is performed. The histogram of all observations is captured as figure 13.

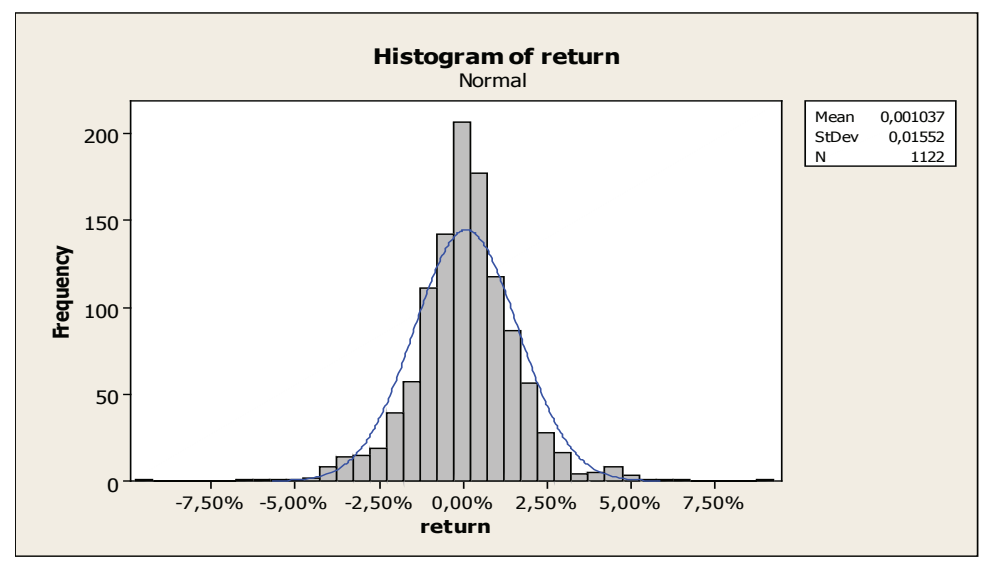

Figure 13. Histogram of JII return (1122 observations) from $2^{\text {nd }}$ March 2009 to $30^{\text {th }}$ Sept 2013

Figure 13 shows that the return of all observations is not normal. In this case, 5 sigma occurs. 5 sigma is $7.76 \%$. This is calculated by multiplying 5 with standard deviation $(0,01552)$. The gain more than $7,76 \%$ persen happens in the period of three and half year from $2^{\text {nd }}$ march 2009 , i.e., at $26^{\text {th }}$ May 2010. Even, 6 sigma occurs in period of all data. 6 sigma is $9.31 \%$. This is calculated by multiplying 6 with standard deviation $(0,01552)$. The gain more than $9.31 \%$ persen happens in 
the period of three and half year from $2^{\text {nd }}$ march 2009, i.e., at $22^{\text {nd }}$ september 2011 which bear loss $9,43 \%$. This is the evidence that the distribution is not normal. To investigate the normality of distribution, Anderson Darling (AD) test and QQ Plot are used. Figure 14 shows the result.

From figure 14 it could be concluded that the distribution of all observations is not normal. Anderson Darling (AD) test is 8,538 with P-Value $<0.005$. This means that the null hypothesis is rejected. The null hypothesis is the distribution is normal. When the null hypothesis is rejected, it means that the distribution is not normal.

Now, the result shows normality in small sample (100 observations) and non normality in larger sample (300 observations, 600 observations, 900 observations and 1122 observations). This confirms that the volatility in large sample is bigger than small sample.

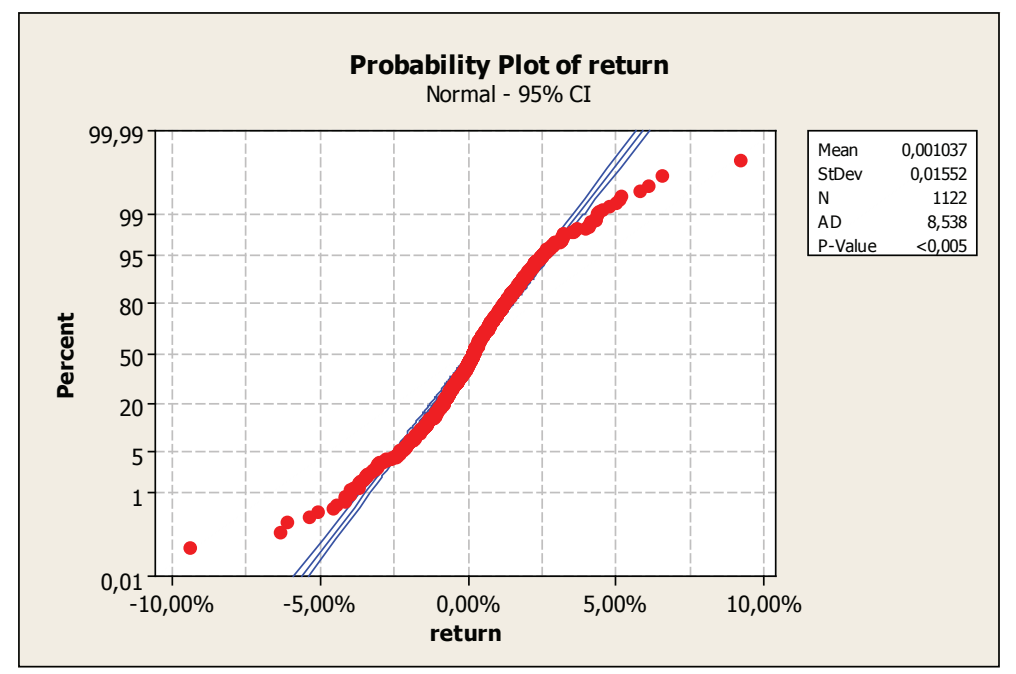

Figure 14. Probability Plot of JII Return (1122 observations) from $2^{\text {nd }}$ March 2009 to $30^{\text {th }}$ Sept 2013

\section{CONCLUSION}

The data of small sample which is 100 observations shows that the distribution of the return of Jakarta Islamic Index is normal. The data of larger sample which is 300 observations shows that the distribution of the return of Jakarta Islamic Index is not normal, even 5 sigmas occur. The data of larger sample which is 600 observations shows that the distribution of the return of Jakarta Islamic Index is not normal, even 6 sigmas occur. 
The data of larger sample which is 900 observations shows that the distribution of the return of Jakarta Islamic Index is not normal, even 6 sigmas occur. The data of larger sample which is 1122 observations shows that the distribution of the return of Jakarta Islamic Index is not normal, even 6 sigmas occur. The volatility of Jakarta Islamic Index varies from time to time. The volatility of larger sample is bigger than small sample.

\section{REFERENCES}

Asteriou, D. \& C. Siriopoulos. 2000. The Role of Political Instability in Stock Market Development and Economic Growth: The Case of Greece. Economic Notes, Volume 29, Issue 3. 2000.

Ausloos, M, 2000. Statistical Physics In Foreign Exchange Currency And Stock Markets. Physica A, 285.

Bagella, M, et.al. 2000. The First Shall Be Last. Size And Value Strategy Premia At The London Stock Exchange. Journal of Banking \& Finance, 24.

Ball, C. A, \& W. N. Torous. 2000. Stochastic Correlation Across International Stock Markets. Journal of Empirical Finance, 7(4).

Bekaert, G, \& C.R. Harvey. 2000. Foreign Speculators and Emerging Equity Markets. Journal of Finance, 55.

Butt, B. Z. 2010. Economic Forces and Stock Market Returns: A Cross Sectoral Study testing Multifactor Model (Disertation). Islamabad: Foundation University.

Cha, B, \& S. Oh. 2000. The Relationship Between Developed Equity Markets and The Pacific Basin's Emerging Equity Markets. International Review of Economics and Finance, 9.

Chan, K., et.al. 2000. Overnight Information and Intraday Trading Behavior: Evidence From NYSE Cross-Listed Stocks and Their Local Market Information. Journal of Multinational Financial Management, 10.

Chordia, T, et.al. 2001. Trading Activity and Expected Stock Returns. Journal of Financial Economics, 59, 3-32.

Dellas, H, \& M. Hess. 2001. Financial Development and The Sensitivity of Stock Markets to External Influences. CEPR Paper No.2766, Social Science Electornic Publishing.

Doukas, J, \& L.N. Switzer. 2000. Common Stock Return and International Listing Announcements: Condititional Tests of the Mid Segmentation Hypothesis. Journal of Banking and Finance, 24, 471-502.

Edwards, Sebastian, et.al. 2003. Stock Market Cycles, Financial Liberalization, and Volatility. Journal of International Money and Finance 22.

Green, C.J, et.al. 2000. Regulatory Lessons for Emerging Stock Markets From A Century 
of Evidence on Transactions Costs and Share Price Volatility in The London Stock Exchange. Journal of Banking and Finance, 24.

Hwang, S, \& S.E. Satchell. 2000. Market Risk and The Concept Of Fundamental Volatility: Measuring Volatility Across Asset and Derivative Markets and Testing for The Impact of Derivatives Markets on Financial Markets. Journal of Banking \& Finance, 24.

Igbatayo, S. 2011. The Challenges of the Global Economic Crisis and Nigeria's Financial Markets' Stability. Journal of Emerging Trends in Economic and Management Sciences (JETEMS), 2(6), 2011.

Kaizoji, T. 2000. Speculative Bubbles and Crashes in Stock Markets: An Interesting Agent Model of Speculative Activity. Physica A, 287.

Kim, K. A. 2001. Price Limits and Stock Market Volatility. Economics Letters, 71.

Lowenstein, R. 2001. When Genius Failed: The Rise and Fall of Long Term Capital Management. United States: Random House.

Miller, J.I. \& R.A. Ratti. 2009. Crude Oil and Stock Markets: Stability, Instability, and Bubbles. Energy Economics. Vol. 31. Issue 4, July 2009.

Mishkin, F. \& E.N. White. 2002. U.S. Stock Market Crashes and Their Aftermath: Implications for Monetary Policy. NBER Working paper No. 8992.

Panetta, F. 2002. The stability of the Relation between the Stock Market and Macroeconomic Forces. Economic Notes. Vol. 31. Issue 3.

Stiglitz, J.E. 2000. Capital Market Liberalization, Economic Growth, and Instability. World Development. Vol. 28. No. 6.

Voth, H.J. 2001. Inflation, Political Instability and Stock Market Volatility in Interwar Germany. Economic Working Papers. No. 535. Department of Economic and Business, Universitat Pompeu Fabra.

Yusof, R.M. \& M.S.A. Madjid. 2007. "Stock Market Volatility Transmission in Malaysia: Islamic Versus Conventional Stock Market”. J.KAU: Islamic Econ., Vol. 20, No. 2, pp: 17-35, 2007. 